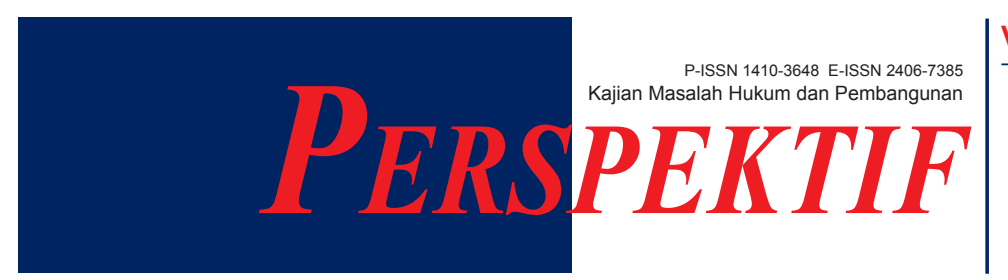

\title{
TEORI EKONOMI SEBAGAI DASAR PERTIMBANGAN DALAM UPAYA MEWUJUDKAN KEMANFAATAN TERKAIT PENJATUHAN SANKSI PIDANA TENTANG HARTA KEKAYAAN DI INDONESIA
}

\author{
Achmad Ardiansyah \\ Magister Ilmu Hukum, Fakultas Hukum, Universitas Airlangga \\ e-mail: achmadardiansyah.attorney@gmail.com
}

\begin{abstract}
ABSTRAK
Penelitian ini bertujuan untuk mengetahui arah perkembangan hukum pidana di Indonesia yang berkaitan dengan teori ekonomi. Penjatuhan sanksi pidana tentang harta kekayaan dalam KUHP yang selama ini masih menciptakan banyak residivis menjadikan perlu adanya perubahan arah penjatuhan sanksi pidana tersebut dengan mempertimbangkan aspek teori ekonomi. Metode penelitian yang dipergunakan adalah metode normatif dengan pendekatan perundang-undangan dan pendekatan konseptual. Hasil penelitian ini mengungkapkan bahwa teori ekonomi sangat berpengaruh terhadap efektifitas penjatuhan sanksi pidana tentang harta kekayaan agar tidak menciptakan pengulangan tindak pidana yang sama sehingga diperlukan adanya perubahan konsep oleh para penegak hukum dalam menjatuhkan sanksi pidana tentang harta kekayaan.
\end{abstract}

Kata Kunci: penjatuhan sanksi; pidana; ekonomi

\begin{abstract}
The study aimed to identify the direction of development of criminal law in Indonesia that associated relating to economic theory. Imposition of criminal sanctions regarding assets in the Criminal Code (KUHP) which so far still creates many residivists make it necessary to change the direction of the imposition of the criminal sanctions by considering aspects of the level of existence. The research method used is a normative legal research with a statue approach and a conceptual approach. The results of this study reveal that economic theory is very influential on the effectiveness of the imposition of criminal sanctions on assets so as not to create repetition of the same crime so that a change in concept is needed by law enforcers in imposing criminal sanctions on assets.
\end{abstract}

Keywords: imposition of sanctions; criminal; economic

\section{PENDAHULUAN}

Manusia memiliki keinginan yang berbeda-beda, agar berbagai keinginan tersebut tidak mengakibatkan kerugian bagi manusia lain, maka perlu adanya peraturan yang menertibkan berbagai keinginan manusia. Secara alamiah, manusia dimanapun dan kapanpun, pada saat dilahirkan hingga meninggal dunia selalu hidup bersosial. Sebagai individu, manusia cenderung berkumpul dengan manusia yang lain, maka dari itu manusia akan membentuk kelompok dengan manusia lainnya untuk hidup bersama. Kecenderungan berkelompok tersebut mengakibatkan manusia mempunyai sifat sebagai mahluk sosial. Kedaan tersebut telah diketahui sejak jaman dahulu oleh seorang filosofis asal Yunani bernama Aristoteles yang menyebut manusia adalah zoon politicon, yaitu mahluk sosial. ${ }^{1}$

\footnotetext{
${ }^{1}$ Jonaedi Effendi Suharto. (2010). Panduan Praktis Jika Anda Menghadapi Perkara Pidana. Jakarta: Prestasi Pustakarya, h. 2-3.
} 
Sobhi Mahmassani menyatakan bahwa manusia bersosial karena karakternya, yakni sesuai berdasarkan sifat alaminya sebagai mahluk madani, mereka tidak bisa hidup sendiri. Kebiasaan manusia hidup dengan berkelompok dilakukan karena beberapa alasan, yaitu: Keinginan untuk memenuhi makanan dan minuman atau kebutuhan memenuhi ekonomi mereka; Keinginan untuk membela diri; dan Keinginan untuk melanjutkan keturunan. ${ }^{2}$

Ketika menjalani kehidupan berkelompok, mereka memiliki tujuan untuk mencukupi keinginan hidupnya, oleh sebab itu dibutuhkan adanya hubungan atau kontak sosial antara kumpulan manusia yang satu dengan kumpulan manusia yang lainnya agar tercapai tujuan dan melindungi keinginannya. ${ }^{3}$ Oleh karena itu manusia membutuhkan berbagai peraturan dan tatanan yang bisa mengatur hubungan diantara manusia. Awalnya peraturan-peraturan tersebut bersifat sangatlah sederhana, akan tetapi semakin kompleksnya keinginan manusia, membuat permasalahan di antara manusia menjadi semakin rumit yang mengakibatkan peraturan-peraturan yang telah adapun menjadi makin sulit dan makin rumit untuk diterapkan. Untuk tetap menjaga ketertiban di antara manusia, dibutuhkan pihak lain baik dalam pembuatan, pelaksanaan maupun penegakan peraturan-peraturan yang ada agar tetap terjaga ketertiban dan keteraturan dalam kehidupan manusia.

Tujuan paling mendasar adanya peraturan atau hukum menurut Bentham ialah agar terjaga keamanan dan persamaan antar manusia. ${ }^{4}$ Tetapi kenyataan yang ada adalah peraturan hanya bermanfaat bagi setiap manusia yang memiliki kekuatan ekonomi yang berlebih dan memiliki jabatan kekuasaan. Dengan demikian, benarkah apabila hukum dikatakan akan bermanfaat pula bagi manusia yang lemah. Norma hukum tidak berasal dari dalam diri manusia. Norma hukum diterapkan atas sifat lahir manusia atau perbuatan lahiriyah yang dilakukan oleh manusia. Maka dari itu tindakan lahir manusia tidak akan menjadi persoalan ketika tidak melanggar norma hukum itu sendiri. Contoh permasalahannya adalah apabila kendaraan diberhentikan oleh pengemudinya

${ }^{2}$ R. Soeroso. (1993). Pengantar Ilmu Hukum. Jakarta: Sinar Grafika, h. 215.

${ }^{3}$ ibid.

${ }^{4}$ Peter Mahmud. (2009). Pengantar Ilmu Hukum. Edisi Pertama. Jakarta: Kencana, h. 121. di persimpangan lampu lalu lintas saat lampu menyala merah adalah karena kesadaran diri atau hanya karena terpaksa. Diberhentikannya kendaraan tersebut kesadaran diri atau pun karena keterpaksaan tidaklah penting bagi penegakan hukum, karena hal terpenting bagi penegakan hukum adalah kendaraan tersebut diberhentikan oleh pengendaranya. Apabila tidak dilaksanakan, maka pengendara tersebut akan dilakukan penindakan tilang. Norma hukum ditujukan khususnya terhadap pelaku yang konkrit, yang merupakan pelanggar peraturan yang telah ada.

Pembangunan nasional berkelanjutan yang sudah direncanakan dan dilaksanakan di Indonesia pada tahun 1970-an, bahkan hingga saat ini bertumpu pada pembangunan ekonomi nasional, yang dipandang sebagai tulang punggung pembangunan nasional di segala bidang. Pembangunan ekonomi nasional didesain untuk meningkatkan taraf hidup masyarakat dan kesejahteraan bangsa. Keberhasilan pembangunan ekonomi nasional juga telah menjadi tolak ukur kemajuan bangsa-bangsa di seluruh negara. Globalisasi pada abad ke-20 dan 21 telah menjadi ideologi seluruh bangsa dunia, bertujuan untuk mencapai kesejahteraan seluruh bangsabangsa dengan menggunakan parameter keberhasilan pertumbuhan ekonomi nasional setiap negara. ${ }^{5}$

Konsep pembangunan hukum nasional telah dicanangkan oleh Muchtar Kusumaatmadja pada tahun 1970-an melalui teori hukum pembangunan dan kemudian menjadi bagian dari pembangunan REPELITA II era Soeharto, memang saat teori hukum ini dikembangkan masih belum disertakan parameter tolak ukur keberhasilan dalam mencapai cita kepastian hukum, keadilan dan kemanfaatan bagi masyarakat Indonesia. Pertimbangan yang dikemukankan ketika itu ialah bahwa pembangunan hukum tidak sama dengan pembangunan sarana dan prasarana fisik karena pembangunan hukum diartikan sebagai proses perubahan sikap mental dalam mematuhi hukum yang berlaku dan memfungsikan peranan hukum dalam membawa kemajuan masyarakatnya. Inti dari pembangunan hukum tidaklah mempunyai standar tolak ukur yang pasti terkait keberhasilannya mengapai citacita kesejahteraan dan kemakmuran bangsa. Maka berdasarkan pertimbangan hal tersebut, maka analisis

\footnotetext{
${ }^{5}$ Romli Atmasasmita. (2018). Pengantar Hukum Kejahatan Bisnis. Edisi Ketiga. Jakarta: Prenadamedia Group, h. 9.
} 
tentang ekonomi dapat membantu ilmu hukum untuk menemukan jawaban yang tepat dan terukur terkait keberhasilan penerapan hukum dalam bermasyarakat dengan tujuan membangun politik hukum yang baik untuk masa mendatang. ${ }^{6}$

Selain pertimbangan di atas, memahami analisis ekonomi penting diketahui oleh para ahli hukum Indonesia karena hukum merupakan peraturan yang berjalan dengan fleksibel atau merupakan "law in the making" (Satjipto Rahardjo), maksudnya adalah hukum tidak berada dalam sifat status quo, melainkan hukum akan terus dalam keadaan berproses untuk menggali (in searching) dan menciptakan (inventing) solusi terkait efisiensi serta efektivitas penerapan peraturan atau hukum di lingkungan masyarakat untuk menggapai ketiga tujuan hukum itu sendiri. Hambatan para ahli hukum untuk menemukan hukum (baru) adalah dipengaruhi oleh pernyataan Van Kan bahwa hukum akan selalu tertinggal daripada perkembangan sosial dalam masyarakat, suatu pendapat yang bertolak belakang bahkan tidak lagi relevan dengan perkembangan masyarakat di era globalisasi, terutama kemajuan teknologi yang sangat memerlukan hukum dapat berfungsi dan berperan dalam mengantisipasi kemungkinan dampak suatu kebijakan politik di masa yang lebih modern. Muladi serta Barda Nawawi Arief menyatakan bahwa kemajuan teknologi masyarakat seringkali membawa dampak sampingan antara lain kejahatan komputer. ${ }^{7}$ Bahkan Mochtar Kusumaatmadja secara tidak langsung telah membantah pendapat Van Kan tersebut dengan menyampaikan Teori Hukum Pembangunan yang menempatkan fungsi dan peranan hukum dalam pembangunan yang lebih baik dari masa sebelumnya. Karenanya analisis ekonomi dapat melengkapi fungsi dan peranan hukum dalam melakukan prediksi pembangunan hukum pada masa mendatang dengan hasil nyata yang pasti dan terukur.

Pembukaan UUD 1945 dalam alinea Keempat, telah dinyatakan secara eksplisit antara lain, “... untuk membentuk Pemerintah Negara Indonesia ... untuk mempertahankan kesejahteraan umum dan ikut melaksanakan ketertiban dunia". Pernyataan

${ }^{6}$ Romli Atmasasmita dan Kodrat Wibowo. (2016). Analisis Ekonomi Mikro Tentang Hukum Pidana Indonesia. Edisi Pertama. Jakarta: Prenadamedia Group, h. 9.

${ }^{7}$ Muladi dan Barda Nawawi Arief. (1992). Bunga Rampai Hukum Pidana. Bandung: Alumni, h. 4. ini kemudian diwujudkan dalam ketentuan dalam Batang Tubuh UUD 1945, khusus terkait Bab Pertama terkait Bentuk Serta Kedaulatan NKRI, dalam Pasal 1 ayat (3), "Negara Indonesia adalah Negara hukum; dan dalam Bab XI tentang Kekuasaan Kehakiman, serta Bab XIV tentang Perekonomian Nasional dan Kesejahteraan Sosial, khususnya Pasal 33". Ketentuan yang dituangkan dalam UUD 1945 tersebut seharusnya diartikan sebagai arah yang dapat menciptakan kolaborasi yang konstruktif antara disiplin ilmu ekonomi dan disiplin ilmu hukum dalam mewujudkan cita-cita pendiri NKRI. Kolaborasi tersebut merupakan bagian terpenting dari komunitas ilmu pengetahuan yang sepatutnya tidak hanya bersikukuh pada dunia ilmu masing-masing dan yang paling benar sendiri, melainkan merupakan amanah dan petunjuk untuk saling berbagi informasi dan pengetahuan satu sama lain, hanya dengan satu tujuan yaitu bersama-sama dan bekerja sama memajukan kesejahteraan rakyat Indonesia. ${ }^{8}$

Untuk memperkokoh serta mewujudkan sebuah tujuan akhir terkait mekanisme peradilan pidana di Republik Indonesia yang bermanfaat bagi seluruh rakyat, diperlukan adanya sedikit perubahan khususnya dalam penerapan penjatuhan sanksi pidana tentang harta kekayaan dalam KUHP. Hal tersebut yang mendasari dilakukannya penelitian hukum ini.

\section{RUMUSAN MASALAH}

Arah perkembangan pendekatan terhadap hukum guna mewujudkan kemanfaatan terkait penjatuhan sanksi pidana terkait harta kekayaan dalam KUHP Indonesia.

\section{METODE PENELITIAN}

Metode penelitian yang dipergunakan merupakan metode penelitian secara normatif dengan melakukan pendekatan melalui perundang-undangan serta pendekatan secara konseptual.

\section{PEMBAHASAN}

Pengertian hukum pidana secara tradisional merupakan hukum yang memuat tentang peraturanperaturan yang mengandung keharusan dan larangan terhadap pelanggaranyang diancam dengan hukuman berupa siksaan badan. Hukum pidana dapat

\footnotetext{
${ }^{8}$ Romli Atmasasmita dan Kodrat Wibowo. op.cit., h. 9-10.
} 
dipandang sebagai suatu bidang hukum yang mandiri, tetapi dalam kesempatan lain bisa pula berposisi suplementer terhadap bidang hukum yang lain.

Sebagai suatu bidang hukum yang mandiri, hukum pidana memiliki kaidah-kaidah tersendiri beserta sanksi pidananya yang dituangkan dalam bentuk perundang-undangan tersendiri. Sementara dalam posisi suplementer, ketentuan hukum pidana disertakan dalam suatu perundang-undangan yang sebenarnya merupakan ketentuan hukum administrasi. Dalam perkembangan kontemporer, posisi suplementer ini semakin banyak didapati dalam banyak perundang-undangan, termasuk dalam kategori hukum ekonomi. ${ }^{9}$

Pengertian tentang Hukum pidana di uraikan oleh beberapa ahli, diantaranya:

Pertama, Moeljatno pernah berpendapat, yaitu bahwa hukum pidana ialah bagian dari keutuhan hukum atau peraturan yang diterapkan di sebuah Negara tertentu, dengan menciptakan dasar-dasar dan peraturan-peraturan dengan tujuan untuk: a. Mempertimbangkan tindakan-tindakan apa saja yang diperbolehkan dan tidak diperbolehkan untuk dilakukan oleh seseorang, yang dilarang tindakannya, dan diikuti dengan berbagai ancaman dan/atau sanksi tertentu yang berupa suatu pidana atau kesengsaraan bagi setiap orang yang melanggarnya; $b$. Mempertimbangkan kapan serta dalam kondisi bagaimana kepada setiap orang yang telah melakukan pelanggaran hukum dapat diterapkan sanksi atau dapat diterapkan pidana sebagaimana telah disanksikan atas perbuatannya; c. Mempertimbangkan menggunakan cara seperti apa penjatuhan pidana tersebut dapat dilakukan jika terdapat orang yang disangkakan telah melakukan pelanggaran hukum. ${ }^{10}$

Kedua, Soedarto berpendapat dengan memberikan batas terkait makna dari hukum pidana selaku peraturan hukum, hal tersebut diikatkan dengan sebuah tindakan yang telah terpenuhinya beberapa syarat yang telah ditentukan dengan sebuah akibat berupa kesengsaraan atau pidana. Maka dari pernyataan tersebut diketahui bahwa pada hakikatnya

${ }^{9}$ Arif Rohman. "Upaya Menekan Angka Kriminalitas Dalam Meretas Kejahatan Yang Terjadi Pada Masyarakat. Jurnal Perspektif. Volume 21 No. 2 Tahun 2016 Edisi Mei, h. 127.

${ }^{10}$ Didik Endro. (2013). Hukum Pidana. Surabaya: Airlangga University Press (AUP), h. 3. hukum pidana bertumpu pada dua hal sebagai berikut: a. Tindakan yang memenuhi beberapa syarat yang telah ditentukan. Dimaksudkan tentang tindakan yang diperbuat oleh seseorang, yang mengakibatkan tercapainya syarat yang memungkinkan dilakukannya penjatuhan sanksi pidana. Tindakan seperti itu dapat pula disebut sebagai "tindakan yang dapat dipidana" atau disingkat "tindakan jahat" ini harus memenuhi syarat "terdapat orang yang telah melakukan tindakan yang dimaksud", maka permasalahan terkait "tindakan tertentu" tersebut dirinci dalam 2 hal, yaitu tindakan yang dilarang dan orang yang telah melanggar larangan atas tindakan tersebut. $b$. Kesengsaraan atau Pidana. Merupakan kesengsaraan yang secara sengaja dibebankan atau diberlakukan kepada setiap orang atau kelompok yang telah bertindakan sesuatu yang menjadikan terpenuhinya berbagai syarat yang dimaksud dalam hukum. Dalam peraturan hukum pidana saat ini, pidana dapat pula mencakup sesuatu hal yang dikatakan sebagai "tindakan tata tertib" (tuchmaatregel, Masznahme). Dalam bidang keilmuan hukum adat Ter Haar dipakailah istilah dalam adat yaitu, reaksi. Di dalam kitab hukum pidana saat ini telah berlaku berbagai jenis pidana yang setiap saat dapat diterapkan yang tertulis dalam Pasal 10 KUHP.

Ketiga, Simons menyatakan beberapa hal sebagai berikut: a. Semua tindakan yang dilarang dan/atau tindakan yang diperintahkan oleh negara atau penegak hukum untuk dilarang, dan diancam dengan kesengsaraan, yaitu sebuah "pidana" apabila ada orang yang melanggar; $b$. Semua peraturan yang menentukan berbagai syarat untuk menjatuhkan sanksi pidana; dan c. Semua peraturan yang menentukan berbagai dasar terkait dilakukannya penjatuhan sanksi dan penetapan pidana.

Keempat, Van Hamel pernah berpendapat, yaitu hukum pidana adalah keutuhan dari berbagai dasar serta berbagai peraturan yang diyakini oleh para penegak hukum atau negara terkait kewajibannya dalam menjaga ketertiban, yaitu dengan cara melarang apapun yang bertolak belakang dari peraturan yang berlaku (onrecht) serta menjatuhkan sebuah kesengsaraan (pidana) terhadap orang yang telah melakukan pelanggaran atas peraturan yang berlaku. 


\section{Fungsi dan Tujuan Hukum Pidana}

Pengertian secara khusus dari Fungsi hukum atau peraturan pidana ialah hukum pidana berfungsi untuk menjaga kepentingan hukum terhadap tindakan tercela atau merugikan. Satochid Kartanegara menyatakan dalam sebuah buku karangannya yang berjudul "Hukum Pidana" serta Hermien Hadiati K., dalam sebuah buku karanganya yang berjudul "Perkembangan Macam-macam Pidana Rangka Pembangunan Hukum Pidana”, Kepentingan Hukum yang dimaksud adalah:

Pertama, Melindungi Nyawa Manusia. Bagi pelanggar ketentuan hukum tersebut, yaitu tindakan menghilangkan nyawa manusia diancam atas tindakannya tersebut dengan berbagai sanksi diantaranya Pasal 338 dalam KUHP. Apabila tindakan yang dilakukannya tersebut disertai dengan sebuah perencanaan, maka akan diancam dengan sanksi Pasal 340 KUHP. Berlaku pula dengan tindakan atau perbuatan yang dilakukan dengan sebab kealpaannya, sehingga mengakibatkan hilangnya nyawa seseorang, maka diancam atas tindakannya tersebut dengan sanksi Pasal 359 dalam KUHP.

Kedua, Melindungi Tubuh (Badan Manusia). Sanksi pidana diancamkan setiap manusia yang melakukan tindakan ataupun perbuatan yang dinilai bisa membahayakan tubuh (badan manusia lain), maka diancam atas tindakannya tersebut dengan sanksi pasal 351 dalam KUHP.

Keempat, Melindungi Kehormatan Manusia. Dalam KUHP terdapat peraturan terkait kehormatan manusia, yaitu ketentuan Pasal 310 KUHP. Maksudnya adalah bagi setiap manusia yang melakukan penyerangan terhadap nama baik atau kehormatan manusia lain, diancam dengan sanksi pidana Pasal 310 KUHP.

Kelima, Melindungi Kemerdekaan Setiap orang. Pasal 333 dalam KUHP dinyatakan ancaman pidana untuk setiap manusia yang dengan keadaan sengaja serta melawan peraturan atau hukum, melakukan tindakan merampas sebuah kemerdekaan orang lain.

Keenam, Melindungi Harta Benda (Kekayaan). Pasal 362 dalam KUHP, ialah salah satu pasal terkait tindakan pencurian harta milik orang lain, dinyatakan bahwa siapa saja dilarang melakukan tindakan atau perbuatan mengambil barang atau harta milik orang lain secara melawan hukum baik atas sebagian maupun seluruhnya. ${ }^{11}$

Sedangkan tujuan hukum pidana adalah: Pertama, Bertujuan untuk menciptakan rasa takut terhadap setiap manusia untuk menghidari sebuah tindakan jahat. Pemberian rasa takut tersebut ditujukan untuk: a. Memberikan rasa takut kepada orang banyak atau kelompok (generale preventive); b. Memberikan rasa takut kepada sebuah kelompok tertentu yang telah bertindak sebuah kejahatan agar di kesesokan hari kelompok tersebut tidak akan mengulangi tindak kejahatannya (special preventive).; Kedua, Bertujuan untuk memberikan pendidikan serta memperbaiki setiap manusia yang telah terindikasi gemar melakukan tindak kejahatan supaya menjadi manusia yang lebih baik prilakunya agar dapat bermanfaat untuk masyarakat.

Wirjono Prodjodikiro berpendapat bahwa dua tujuan di atas adalah tujuan yang sifatnya sekunder atau tambahan. Menurutnya, kedua tujuan di atas akan berperan penting untuk menjaga keseimbangan kemasyarakatan sebagai bentuk tujuan utamanya.

Seperti yang dikutip oleh Andi Hamzah, di sebuah karangan bukunya yang berjudul "AsasAsas Hukum Pidana", Van Bemmelen pernah berpandangan, yaitu hukum pidana adalah sama halnya dengan bagian lain dari peraturan atau hukum itu sendiri, karena keutuhan dari hukum tersebut menentukan aturan-aturan dengan tujuan menegakkan ketentuan-ketentuan yang diyakini oleh perarturan itu sendiri. Terkait hukum pidana, disuatu sisi eksistensinya sedikit berbeda dengan bagian lain dalam hukum atau peraturan, bahwa hukum pidana membicarakan terkait adanya tambahan kesengsaraan atau derita kepada pelanggarnya dengan sengaja ke dalam sebuah keadaan pidana atau penjara, walaupun sebenarnya penjara atau pidana tersebut memiliki fungsi berbeda dengan yang lain dari hanya sekedar menambah kesengsaraan. Keutamaan dari tujuan hukum dari seluruh peraturan atau hukum adalah untuk kedamaian, keadaan tertib masyarakat, kesejahteraan, keadaan tenang di dalam masyarakat, tanpa adanya kesengajaan untuk menciptakan suatu kesengsaraan. ${ }^{12}$

Pada dasarnya, pidana itu ditujukan sebagai suatu penderitaan atau nestapa bagi pelaku tindak

\footnotetext{
11 ibid., h. 5-6.

12 ibid., h. 7.
} 
pidana atas kesalahannya. Adanya penderitaan tersebut dalam bentuk pidana telah mengakibatkan hukum pidana mendapat tempat tersendiri di antara hukum yang lain, yang mana menurut pendapat para sarjana, hukum pidana itu dipandang sebagai ultimum remedium atau sebagai upaya terakhir yang harus dipergunakan untuk memperbaiki tingkah laku manusia. ${ }^{13}$

\section{Pembagian Tindak Pidana}

Strafbaar feit (tindak pidana) adalah sebuah istilah dari bahasa asing (Belanda) dan diartikan atau diterjemahkan ke dalam berbagai macam pengertian, yaitu sebuah tindakan pidana, sebuah perbuatan pidana, delik, sebuah peristiwa pidana serta tindakan yang bisa dipidanakan. Strafbaar feit yang tersusun atas tiga suku kata, yaitu straf, baar serta feit, macam-macam arti yang dimaksudkan terkait pengertian strafbaar feit itu, diketahui bahwa straf dapat diartikan sebagai hukum dan/atau pidana. Istilah baar diartikan sebagai boleh dan dapat, sedangkan istilah feit diartikan sebagai tindakan, pelanggaran, perbuatan, dan peristiwa. ${ }^{14}$

Pompe berpendapat, seperti yang dinyatakan oleh Bambang Poernomo, bahwa maksud dari strafbaar feit dibedakan menjadi: 1. Makna berdasarkan teori memberikan arti bahwa "strafbaar feit" ialah sebuah pelanggaran terhadap ketentuan hukum yang dilakukan akibat kesalahan pelaku, dan diancam dengan sanksi pidana agar mempertahankan tatanan hukum serta menjaga kesejahteraan dan ketertiban umum; 2. Makna berdasarkan hukum positif, memberikan arti bahwa "strafbaar feit" merupakan sebuah tindakan (feit), yang atas ketentuan perundang-undangan dinyatakan dalam sebuah tindakan yang dapat dijatuhi hukuman. ${ }^{15}$

Selaras dengan pengertian atau definisi berdasarkan teori serta hukum positif tersebut, J.E Jonkers turut menyatakan pendapat terkait definisi strafbaar feit yang diuraikan menjadi dua definisi, sebagaimana yang telah dinyatakan oleh Bambang Pornomo, ialah sebagai berikut: 1 .

13 Suhariyono AR. "Perumusan Sanksi Pidana Dalam Pembentukan Peraturan Perundang-undangan". Jurnal Perspektif. Volume 17 No. 2 Tahun 2012 Edisi Januari, h. 21.

${ }^{14}$ Adami Chazawi. (2002). Pengantar Hukum Pidana Bagian 1. Jakarta: Grafindo, h. 69.

${ }^{15}$ Bambang Poernomo. (1992). Asas-Asas Hukum Pidana. Jakarta: Ghalia Indonesia, h. 91.
Menurut pengertian singkat, diberikan pengertian atas "strafbaar feit", ialah sebuah tindakan (feit), yang apabila dilakukan bias diterapkan sanksi pidana oleh hukum atau peraturan yang berlaku; 2 . Menurut pengertian yang lebih panjang, diberikan definisi terkait "strafbaar feit", ialah sebuah tindakan yang bertentangan dengan hukum, dilakukan baik atas sebuah maksud kesengajaan atau kealphaan oleh setiap manusia atau kelompok manusia yang dinilai dapat mempertanggungjawabkan perbuatannya.

Berdasarkan pengertian singkat, dalam pokoknya dinyatakan bahwa terkait setiap tindakan yang bisa dipidana haruslah didasarkan kepada peraturan atau hukum yang ditetapkan oleh pembuat peraturan atau hukum sendiri, dan oleh karenanya pendapat orang pada umumnya tidaklah dapat ditentukan sebagai maksud yang berbeda daripada hal-hal yang telah dimaksudkan atau ditetapkan di dalam hukum atau peraturan itu sendiri. Pengertian secara luas lebih mempusatkan pengertian atas adanya sifat bertentangan dengan hukum yang dilakukan oleh setiap manusia (pelaku) dan adanya kemampuan untuk bertanggungjawab yang ditetapkan sebagai bagian dari unsur delik yang sudah ditentukan secara tegas dalam setiap delik, atau unsur tersembunyi yang secara tidak langsung diyakini keberadaannya oleh hukum.

Menurut Simons, sebuah tindak pidana didefinisikan dengan sebuah tindakan dimana tindakan tersebut dijatuhi dengan sanksi pidana oleh peraturan yang berlaku, bertolak belakang dengan kaidah peraturan yang dilakukan atas sebuah kesalahan dari seseorang yang dinilai mampu untuk bisa mempertanggungjawabkan perbuatannya. ${ }^{16}$ Rangkaian definisi sebuah tindak pidana yang dikemukakan oleh Simons dipandang sebagai rangkaian definisi yang paling lengkap dikarenakan hal tersebut mencakup beberapa hal, yaitu: 1. Adanya ancaman dengan pidana; 2. Adanya tindakan yang bertolak belakang kaidah peraturan yang ada; 3 . Tindakan tersebut dilakukan oleh seseorang atas sebuah bentuk kesalahan (schuld); 4. Pelaku yang dimaksud dinilai dapat mempertanggungjawabkan tindakannya.

Pendapat yang dikemukakan oleh Van Hamamel selaras dengan definisi tindak pidana dari Simons,

16 Roni Wiyanto. (2012). Asas-asas Hukum Pidana Indonesia. Bandung: Mandar Maju, h. 160. 
akan tetapi ia memberi tambahan dengan adanya "Tindakan yang mempunyai sifat dapat dihukum". Definisi tindak pidana berdasarkan pendapat yang dikemukakan Van Hammel mencakup lima unsur, yaitu: 1. Adanya ancaman dengan sebuah pidana; 2. Adanya tindakan yang bertolak belakang dengan kaidah peraturan yang ada; 3. Tindakan tersebut dilakukan oleh seseorang atas sebuah bentuk kesalahan (schuld); 4. Pelaku yang dimaksud dinilai dapat mempertanggungjawabkan tindakannya; 5 . Tindakan yang mempunyai sifat dapat dihukum. ${ }^{17}$

Tindak pidana pada dasarnya dipisahkan menjadi beberapa bagian, yaitu: 1. Tindak pidana berupa sebuah kejahatan (misdrijven) serta tindakan pidana berupa sebuah pelanggaran (overtrendingen); 2 . Tindak pidana dengan kesengajaan $($ dolus $=$ Opzet $)$ serta tindakan pidana dengan kealpaan (culpa); 3 . Tindak pidana commisionis, tindak pidana ommisionis, tindak pidana commisionis per ommisionis commisa, yaitu: a. Tindak pidana commisionis adalah sebuah tindakan pelanggaran hukum, misal melanggar Pasal 362, 372 KUHP; b. Tindak pidana ommisionis adalah keadaan tidak bertindak atau enggan berbuat sesuai yang diwajibkan dan/atau diharuskan oleh peraturan yang ada, misal melakukan pelanggaran atas Pasal 165 KUHP; c. Tindak pidana commisionis per ommisionis commisa adalah tindakan yang berbentuk sebuah pelanggaran atas larangan (bertindak halhal yang dinilai melanggar hukum), dalam bentuk tidak bertindak, misal orangtua (ibu) yang tidak mau memberi air susunya (ASI) sehingga bayinya meninggal dunia. 4. Tindak pidana formil dan materiil: a. Tindak pidana formil adalah tindakan yang ketentuannya dititikberatkan kepada tindakan yang tidak boleh dilakukan, misal Pasal 362 dalam KUHP; b. Tindak pidana materiil adalah sebuah tindakan yang ketentuannya dipusatkan kepada adanya efek yang dihindari oleh hukum, misal Pasal 338 dalam KUHP; 5. Tindak pidana tunggal dan berganda; 6 . Tindak pidana yang berkelanjutan dan tindak pidana yang tidak berkelanjutan. Contoh yang berkelanjutan diatur di Pasal 333 dalam KUHP; 7. Tindak pidana biasa serta tindak pidana aduan (klachdelicten). Tindak pidana aduan ada 2 macam, yaitu: a. Tindak pidana aduan absolute, merupakan tindak pidana yang tidak dapat ditetapkan adanya penyidikan apabila belum ada sebuah pengaduan.

17 ibid.
Contohnya: Pasal 310 serta 311 KUHP tentang Pemfitnahan; b. Tindak pidana aduan relative, ialah tindak pidana yang dapat ditetapkan adanya penyidikan sebelum adanya sebuah pengaduan, akan tetapi terkait penuntutan yang akan ditetapkan tidak bisa dilakukan apabila sebelum ada sebuah pengaduan. Contohnya: Pasal 367 dalam KUHP tentang pencurian yang dilakukan oleh keluarga. 8. Tindak pidana yang ada pemberatnya (Pasal 363 KUHP) dan tindak pidana sederhana (Pasal 362 KUHP); 9. Tindak pidana propira, merupakan sebuah tindakan pelanggaran hukum yang dapat diperbuat hanya oleh pihak-pihak yang memiliki kedudukan atau kekuasaan, contohnya Pasal 413 KUHP; 10. Tindak pidana putatief, merupakan tindak pidana yang apabila seseorang melakukan sebuah tindakan yang diperkirakan adalah tindakan yang dilarang serta diancam dengan sanksi pidana oleh hukum, akan tetapi diketahui di kemudian bahwa tindakan tersebut bukan merupakan sebuah tindakan yang tidak diperkenankan (bukan termasuk tindakan pelanggaran hukum). Misalnya diketahui terdapat seseorang yang mengambil suatu benda yang dipikirnya adalah dalam kepenguasaan tuannya, ternyata baru diketahui kemudian jika barang tersebut oleh tuannya telah diberikan kepadanya. ${ }^{18}$

\section{Sanksi Pidana Tentang Harta Kekayaan dalam KUHP}

Tindak pidana tentang harta kekayaan dalam KUHP didefinisikan sebagai sebuah tindakan yang merugikan kepentingan hukum orang lain atas harta kekayaan milik orang lain. Pengaturan tindak pidana tentang harta kekayaan di dalam ketentuan KUHP diatur pada Buku 2 terkait Kejahatan, Bab 22 tentang pencurian, Bab 23 tentang pengancaman dan pemerasan, Bab 24 tentang penggelapan, $\mathrm{Bab}$ 25 tentang tindakan curang, Bab 26 tentang tindakan yang merugikan orang yang mempunyai hak atau yang berpiutang, Bab 27 tentang merusak barang atau menghancurkan, Bab 30 tentang penadahan.

Setiap tindak pidana terkait harta kekayaan memiliki unsur-unsur atau kualifikasi tertentu baik secara objektif maupun subjektif. Adanya kualifikasi atau unsur tersebut menjadi tolak ukur seorang terdakwa, tersangka yang melakukan tindak pidana. Perbedaan yang mendasar di antara berbagai

\footnotetext{
${ }^{18}$ Didik Endro. loc.cit., h. 45-46.
} 
macam tindak pidana tersebut ialah: a. Mengambil barang kepunyaan orang lain supaya dimiliki atau dimanfaatkan secara bertentangan dengan hukum, disebut Tindak Pencurian (diefstal); b. Melakukan pemaksaan kepada orang lain dengan tindakan kekerasan agar memberikan barang miliknya, disebut Pemerasan (afpersing); c. Melakukan pemaksaan kepada orang lain dengan tindakan pengancaman untuk memberikan barang miliknya, disebut Pengancaman (afdreiging); d. Mengelabui orang lain dengan tindakan tipu muslihat agar memberikan barang milik orang lain tersebut, disebut Penipuan (oplichting); e. Memiliki atau menguasai barang yang bukan merupakan haknya, yang sudah ada dalam penguasaannya, disebut Penggelapan (verduistering); f. Sebagai orang yang mempunyai hutang, melakukan suatu tindakan terhadap kekayaannya sendiri yang mengakibatkan kerugian bagi pihak yang berpiutang, disebut Tindakan yang merugikan orang berpiutang; g. Melakukan tindakan terhadap barang milik orang lain yang menyebabkan kerugian tanpa menguasai barang tersebut, disebut Pengerusakan atau Penghancuran barang; h. Tindakan menerima dan/ atau memperlakukan benda yang ia terima dari orang lain dari hasil tindak kejahatan, disebut Penadahan. ${ }^{19}$

\section{Hubungan Teori Ekonomi (Efisiensi, Keseimbangan dan Maksimalisasi) dengan Penjatuhan Sanksi Pidana Tentang Harta Kekayaan}

Peristiwa hukum yang terjadi dalam masyarakat beragam versi, misalnya perkara perdata, perkara pidana atau perkara administrasi; ketiga perkara tersebut sering terjadi dan sering menimbulkan polemic mengenai sanksi yang mana yang harus didahulukan atau diutamakan, hanya dengan satu tujuan agar kehidupan masyarakat pada umumnya dan khususnya pihak pihak yang berperkara dapat memulihkan kembali hubungan sosialnya. Diantara sanksi administrative, sanksi pidana serta perdata, maka sanksi pidana yang dinilai sebagai sebuah sanksi yang diakui sangat keras dan tajam karena secara langsung memberikan efek jera kepada pelaku kejahatan dan keluarganya. Penempatan dalam penjara dan pembatasan kebebasan bergerak serta

19 https://www.google.co.id/amp/s/equalpartners.food. blog/2019/03/08/kejahatan-terhadap-harta-kekayaan/amp/ diakses pada Jumat, 8 Oktober 2020, Pkl 21.00 WIB. kehilangan kebebasan lainnya merupakan keadaan yang menakutkan dan menjerakan. Pandangan tersebut mendorong kehendak pada setiap pemegang kekuasaan dalam suatu negara hukum untuk selalu berpandangan bahwa sanksi pidana dapat diterapkan serta merta pada suatu peristiwa sosial dalam masyarakat tanpa harus mempertimbangkan sanksi lain (sanksi administratif dan sanksi perdata) hanya karena sanksi pidana dianggap efektif menghentikan setiap orang yang akan melakukan kejahatan dan dianggap satu-satunya sanksi yang dapat membuat jera pelakunya. ${ }^{20}$

Sejarah perkembangan hukum pidana yang terjadi di beberapa negara, terutama kejahatan terhadap nyawa dan badan, hampir dapat dipastikan bahwa sanksi hukuman penjara dipandang efektif dan menjerakan pelakunya; suatu pandangan utilitarianisme ala Jeremy Bentham dengan teori felicific calculus ${ }^{21}$ atau keseimbangan antara keseriusan kejahatan dan sanksi yang seimbang. Sanksi pidana denda sangat jarang diterapkan dengan pertimbangan hanya dapat dan layak diterapkan terhadap kejahatan-kejahatan yang bertujuan untuk mencari keuntungan finansial atau kejahatan di bidang keuangan. Namun baik sanksi pidana penjara maupun sanksi denda masih tetap berpijak pada pandangan bahwa, "man is a rational-actorand immoral" $" 22$ yang bisa membuat pertimbangan terkait untung maupun rugi dari kejahatan yang akan dilakukannya. ${ }^{23}$

Maksimalisasi dalam konteks kejahatan terutama tindakan jahat yang diperbuat oleh perusahaan (korporasi) dan/atau kelas menengah dilakukan dengan mempertimbangkan antara kemungkinankemungkinan untuk mendapatkan untung-rugi dari perbuatannya. Bentuk keuntungan tersebut adalah keuntungan dari hasil perbuatannya dan rugi tersebut ialah rugi dalam bentuk materiil dan imateriil pada

\footnotetext{
${ }^{20}$ Romli Atmasasmita dan Kodrat Wibowo. loc.cit., h. 77.

${ }^{21}$ Jeremy Bentham, "An Introduction to the Principles of Morals and Legislation" (1843). Bernard Arif Sidharta, 2000, Refleksi Tentang Struktur Ilmu Hukum, Sebuah Penelitian Tentang Fundasi Kefilsafatan dan Sifat Keilmuan Ilmu Hukum sebagai Landasan Pengembangan Ilmu Hukum Nasional Indonesia. Bandung: Mandar Maju.

${ }^{22}$ Michael Trebilcock dalam Megan Richardson and Gilian Hafield. (1999). "The Second Wave of Law and Economics". The Federation Press.

${ }^{23}$ Romli Atmasasmita dan Kodrat Wibowo. op.cit., h. 7778
} 
korban perbuatannya (perseorangan, perseroan, bahkan negara sekalipun), dan pertimbangan kerugian yang kelak ia alami karena ditangkap dan ditahan serta dihukum. Dalam konteks hukum pidana, keseimbangan seharusnya dapat memberikan jalan keluar atas sebuah masalah, yaitu dengan adanya kepedulian penegak hukum dengan mempertimbangkan pertanyaan bagaimanakah kerugian yang dialami oleh korban bisa digantikan oleh tersangka tindakan jahat; dapatkah dilakukan dengan pemenuham kompensasi atau dilakukan melalui penjatuhan hukuman yang sesuai sebagai efek dari perbuatannya. Namun, penetapan sanksi yang diterapkan atas sebuah kejahatan wajib ditentukan dengan pertimbangan adanya prinsip efisiensi, karena hal tersebut sangat berkaitan dengan adanya pertanyaan apakah penetapan pidana denda dan/atau pidana penjara lebih efisien ataukah pemenuhan kompensasi kepada korban atau pemenuhan kembali kerugian keuangan negara oleh pelaku dinilai lebih berkeadilan daripada menjalani hukuman pidana dalam kurun waktu tertentu. ${ }^{24}$

Becker secara spesifik mengemukakan analisis antara ekonomi dengan hukum pidana, yaitu: Keseimbangan antara beratnya hukuman dan kepastian hukum; Pertimbangan yang seimbang secara nilai ekonomi antara penjatuhan penjara dengan penjatuhan denda; Pertimbangan nilai ekonomi berdasarkan sisi hukum acara dan penegakan hukum; Efek pencegahan dan efek jera dari hukuman penjara (termasuk ketentuan hukuman mati).

Keempat lingkup objek analisis ekonomi dari Becker di atas menitikberatkan pada keterkaitan antara perbuatan hukum dengan hukuman di satu sisi, dan atara hukuman penjara dan hukuman denda di sisi lain, khusus mengenai efeknya terhadap pelaku tindak pidana. Bagi penganut paham hukum pidana klasik yang mengutamakan penjeraan tentu analisis ekonomi terhadap hukum pidana dari Becker akan diabaikan dan tidak mendapatkan perhatian dari mereka untuk dikaji lebih lanjut karena bagi mereka penjeraan lebih penting dari kegunaan atau kemanfaatan, ataupun efisiensi bekerjanya hukum pidana. Namum bagi penganut paham hukum pidana modern, keempat objek tersebut mendapat perhatian yang serius karena mereka beranggapan bahwa sepanjang sejarah hukum pidana, khusus mengenai

24 ibid., h. 81. hukuman, tidak pernah terjadi efek penjeraan yang massif pada pelaku tindak pidana, sebaliknya bahkan residivis semakin meningkat seiap harinya. ${ }^{25}$

Untuk mengetahui tingkat efisiensi dan efektifitas dari penerapan sanksi pidana tentang harta kekayaan didapat melalui aspek filosofis berdasarkan sejarah dari filsafat hukum yang dikemukakan Jeremy Bentham yang tertuang dalam karyanya yaitu, "Introduction to the Principles of Morals and Legislation" (1948) yang memberikan penyataan yang strategis terkait hukum alamiah manusia, "nature of mankind under the government of two sovereign matters, pain and pleasure. It is for them alone to point out what we ought to do as well as to determine what we shall do". Betham menyatakan pendapatnya, yaitu inti dari "what ought to do" diterjemahkan sebagai standard terkait benar (right) serta salah (wrong), sedangkan "what we shall do" harus diterjemahkan sebagai hubungan antara sebab dan akibat. Kedua karakter (pleasure and pains) dalam pernyataan Bentham diartikan dengan selalu menguasai setiap individu baik dalam prilaku, ucapan maupun ketika manusia berfikir. Bentham tampak sangat terobsesi oleh dua karakter manusia tersebut dan pastinya tidak akan berbeda jauh dengan karakter manusia yang dikatakan Thomas Hobbes (1651) dalam sebuah karyanya, "leviathan" bahwa "manusia bagaikan serigala terhadap manusia lainnya; satu sama lain saling menghancurkan" (homo homini lupus bellum omnium contra omnes). ${ }^{26}$

Idealnya dalam mengambil putusan terhadap suatu perkara, hakim mempertimbangkan 4 (empat) elemen, yaitu aspek filosofis, asas-asas hukum, aturan hukum positif dan budaya masyarakat hukum. Penegakan hukum yang mengutamakan kepastian hukum merupakan pandangan yang berlebihan, menjadi kendala masuknya asas-asas hukum dan nilai (keadilan) yang hendak ditegakkan oleh hukum ke dalam putusan pengadilan. Penegakan hukum yang mengabaikan nilai keadilan dapat menjauhkan cita rasa keadilan masyarakat dan pada gilirannya akan mempengaruhi citra hukum di mata masyarakat. ${ }^{27}$

\footnotetext{
25 ibid., h. 83.

${ }^{26}$ ibid., h. 131.

27 Diah Puspita Evariani, Eko Sopoyono, Sularto. "Kebijakan Pertanggungjawaban Pidana Oleh Pelaku Kejahatan Terhadap Harta Benda (Studi Kasus Terhadap Recidivis)". Diponegoro Law Review. Volume 1 Nomor 2 Tahun 2013, h. 4.
} 


\section{Arah Perkembangan Penjatuhan Sanksi Pidana} Tentang Harta Kekayaan Dalam KUHP Indonesia

Perkembangan hukum dan sistem hukum termasuk hukum pidana, tidak bisa dilepaskan dari politik hukum. M. Machfud MD mengatakan bahwa politik merupakan legal policy atau arah hukum yang akan diberlakukan oleh negara untuk mencapai tujuan negara yang bentuknya dapat berupa pembuatan hukum baru dan penggantian hukum lama. Pengertian yang dikemukakan di atas jelas sangat terbatas pada pengertian pembentukan hukum (rechtvorming) khususnya oleh lembaga legislatif. Untuk itu Machfud MD membedakan antara politik hukum yang tidak hanya menyangkut arah resmi hukum yang diberlakukan, melainkan menyangkut pula berbagai hal yang terkait dengan arah resmi itu misalnya politik yang melatarbelakangi, budaya hukum yang melingkupi dan problem penegakan yang dihadapi. ${ }^{28}$

Romli Atmasasmita menyatakan bahwa nilai (value) dari keputusan menjatuhkan sanksi penjara atas setiap tersangka tindak kejahatan tidaklah sebanding dengan berbagai aspek, yaitu aspek nilai sosial, nilai filosofis, serta nilai ekonomi eksistensi, serta tujuan utama diciptakannya hukum di tengah-tengah masyarakat yang kini tengah membangun dan di tengah-tengah tingkat ekonomi yang hingga saat ini belum seratus persen pulih dari krisis ekonomi 1988. Punishing justice tidak lagi efektif bahkan tidak efisien dan kontra-produktif karena memenjarakan seseorang selama setahun tidak membuat jera, bahkan telah meningkatkan kejahatannya, "penjara sekolah tinggi kejahatan" bukan ungkapan semata tetapi kenyataan yang terjadi dalam kehidupan penjara sehari-hari. Peranan dan fungsi hukum terkait rencana pembangunan nasional Negara Indonesia secara spesifik dinyatakan oleh Mochtar Kusuma Atmadja serta S. Raharjo, serta disandingkan dan diperbandingkan dengan pendapat Romli Atmasasmita yang mengemukakan premis yang dapat disebut sebagai teori hukum integratif. Premis teori hukum integratif yang dimaksud adalah: "Hukum yang mengutamakan norma dan logika kehilangan arti dan makna jika tidak berhasil

${ }^{28}$ Yoserwan. "Kebijakan Hukum Pidana Mengenai Pidana Tentang Harta Kekayaan dalam RUU KUHP Indonesia Sebagai Antisipasi Kelebihan Kapasitas di Lembaga Pemasyarakatan”. Jurnal Legislasi Indonesia. Vol. 17 No. 2 Juni 2020, h. 180-192. diwujudkan dalam sistem perilaku birokrasi dan masyarakat yang sama-sama taat hukum. Sebaliknya hukum yang hanya dipandang sebagai sistem norma dan perilaku saja dan digunakan sebagai mesin birokrasi, akan kehilangan rohnya jika mengabaikan sistem nilai yang bersumber pada Pancasila sebagai puncak nilai kesusilaan dalam kehidupan berbangsa dan bernegara". ${ }^{29}$

Bab I UUD 1945 telah menyatakan bahwa Indonesia merupakan Negara hukum, sedangkan Bab IV menegaskan bahwa kesejahteraan sosial merupakan tujuan pendirian Negara Kesatuan Republik Indonesia yang merujuk pada perekonomian demi kepentingan rakyat. Ketentuan UUD 1945 tersebut memberikan sinyal kepada khususnya para ahli hukum dan ahli ekonomi untuk berjuang bersama-sama menciptakan tujuan hukum tersebut. Romli juga mengatakan bahwa jika para ahli hukum memiliki keinginan kuat untuk menjadikan hukum sebagai sarana pembangunan, seharusnya faktor efisiensi, keseimbangan dan maksimalisasi dimasukkan ke dalam penerapan maupun pembentukan hukum, serta dengan melalui cara tersebutlah hukum di Indonesia dapat dikatakan sebagai hukum modern (masa depan), bukan hanya hukum di masa dahulu semata. ${ }^{30}$

Berdasarkan keinginan tersebut, maka pendekatan terhadap hukum ke depan seharusnya bukan ex-ante akan tetapi juga post-factum. Inti dari pendekatan terbaru (bagi Indonesia) adalah bahwa berhasilnya fungsi hukum sebagai sebuah bentuk upaya rekayasa masyarakat, sebagai sistem nilai dan perilaku aparatur hukum ditekankan bukan hanya kepada output melainkan juga outcome. Perubahan pendekatan ex-ante kepada post-factum dengan tujuan outcome yang signifikan dalam memfungsikan hukum sebagai sarana rekayasa sosial, rekayasa perilaku yang dilandaskan pada sistem nilai Pancasila dapat dikaitkan dalam suatu interelasi dan interpendensi antara tujuan hukum dan prinsipanalisis ekonomi (harta kekayaan). Keadilan tepat apabila disandingkan dengan kualifikasi efisiensi dalam teori ekonomi dikarenakan kesejahteraan bagi seluruh rakyat dapat terpenuhi apabila setiap individu masyarakat merasakan bentuk kepuasan yang sederajat dengan bentuk pengorbanan yang

\footnotetext{
${ }^{29}$ Romli Atmasasmita. loc.cit., h. 21-23.

${ }^{30}$ ibid., h. 23-24.
} 
dilakukannya atas sumber dayanya, masyarakat yang ingin keadilan merasa terpuaskan dengan apa yang mereka dapat, sedangkan pelaku atau terpidana merasa terpuaskan dengan hukuman yang dia terima dikarenakan hukuman tersebut merupakan resiko rasional atas tindakan melanggar hukum yang dilakukannya.

Keseimbangan disandingkan dengan kepastian hukum yang diterjemahkan bahwa keuntungan yang diinginkan atas tindak pidana yang dilakukan oleh yang pelaku telah dinikmatinya, oleh karenanya pelaku dijatuhi hukuman yang sesuai atau sederajat dengan bentuk kerugian yang dialami atau diderita korban atas tindakan kejahatan yang dilakukannya. Kemanfaatan disejajarkan dengan maksimalisasi diterjemahkan bahwa para penegakan keadilan harus dapat memberikan sebuah kemanfaatan yang maksimal guna jaminan kepastian hukum bagi pencari keadilan serta guna kepentingan perlindungan hukum itu sendiri. Untuk memperkokoh serta mewujudkan sebuah tujuan akhir terkait mekanisme peradilan pidana di Republik Indonesia, diperlukan adanya sedikit perubahan atas asas hukum pidana yang klasik, yaitu asas legalitas, dari yang semula asas "tiada pidana tanpa kesalahan", berubah menjadi sebuah asas "tiada pidana tanpa kesalahan, tiada kesalahan tanpa kemanfaatan". ${ }^{31}$

\section{PENUTUP}

\section{Kesimpulan}

Inti dari arah pendekatan terbaru (bagi Indonesia) adalah bahwa berhasilnya fungsi hukum sebagai sebuah bentuk upaya rekayasa masyarakat, sebagai sistem nilai dan perilaku aparatur hukum ditekankan bukan hanya kepada output melainkan juga outcome. Perubahan pendekatan ex-ante kepada post-factum dengan tujuan outcome yang signifikan dalam memfungsikan hukum sebagai sarana rekayasa sosial, rekayasa perilaku yang dilandaskan pada sistem nilai Pancasila dapat dikaitkan dalam suatu interelasi dan interpendensi antara tujuan hukum dan prinsipanalisis ekonomi (harta kekayaan). Keadilan tepat apabila disandingkan dengan kualifikasi efisiensi dalam teori ekonomi dikarenakan kesejahteraan bagi seluruh rakyat dapat terpenuhi apabila setiap individu masyarakat merasakan bentuk kepuasan yang sederajat dengan bentuk pengorbanan yang

\footnotetext{
31 ibid., h. 24-26.
}

dilakukannya atas sumber dayanya, masyarakat yang ingin keadilan merasa tepuaskan dengan apa yang mereka dapat, sedangkan pelaku atau terpidana merasa terpuaskan dengan hukuman yang dia terima dikarenakan hukuman tersebut merupakan resiko rasional atas tindakan melanggar hukum yang dilakukannya.

Keseimbangan disandingkan dengan kepastian hukum yang diterjemahkan bahwa keuntungan yang diinginkan atas tindak pidana yang dilakukan oleh yang pelaku telah dinikmatinya, oleh karenanya pelaku dijatuhi hukuman yang sesuai atau sederajat dengan bentuk kerugian yang dialami atau diderita korban atas tindakan kejahatan yang dilakukannya. Kemanfaatan disejajarkan dengan maksimalisasi diterjemahkan bahwa para penegakan keadilan harus dapat memberikan sebuah kemanfaaatan yang maksimal guna jaminan kepastian hukum bagi pencari keadilan serta guna kepentingan perlindungan hukum itu sendiri.

\section{Rekomendasi}

Arah perkembangan pendekatan terhadap hukum ke depan seharusnya bukan hanya ex-ante akan tetapi juga post-factum. Untuk memperkokoh serta mewujudkan sebuah tujuan akhir terkait mekanisme peradilan pidana di Republik Indonesia, diperlukan adanya sedikit perubahan atas asas hukum pidana yang klasik, yaitu asas legalitas, dari yang semula asas "tiada pidana tanpa kesalahan", berubah menjadi sebuah asas "tiada pidana tanpa kesalahan, tiada kesalahan tanpa kemanfaatan".

\section{DAFTAR PUSTAKA}

\section{Peraturan Perundang-undangan:}

Undang-undang Dasar Republik Indonesia Tahun 1945.

Kitab Undang-undang Hukum Pidana (KUHP).

\section{Buku:}

Adami Chazawi. (2002). Pengantar Hukum Pidana Bag 1. Jakarta: Grafindo.

Bambang Poernomo. (1992). Asas-asas Hukum Pidana. Jakarta: Ghalia Indonesia.

Didik Endro. (2013). Hukum Pidana. Surabaya: Airlangga University Press (AUP).

Jeremy Bentham, "An Introduction to the Principles of Morals and Legislation” (1843). Bernard 
Arif Sidharta, Refleksi Tentang Struktur Ilmu Hukum, Sebuah Penelitian Tentang Fundasi Kefilsafatan dan Sifat Keilmuan Ilmu Hukum sebagai Landasan Pengembangan Ilmu Hukum Nasional Indonesia. Mandar Maju, Bandung, 2000.

Jonaedi Effendi Suharto. (2010). Panduan Praktis Jika Anda Menghadapi Perkara Pidana. Jakarta: Prestasi Pustakarya.

Michael Trebilcock dalam Megan Richardson and Gilian Hafield. (1999). "The Second Wave of Law and Economics". The Federation Press.

Muladi dan Barda Nawawi Arief. (1992). Bunga Rampai Hukum Pidana. Bandung: Alumni.

Peter Mahmud. (2009). Pengantar Ilmu Hukum. Edisi Pertama. Jakarta: Kencana.

R. Soeroso. (1993). Pengantar Ilmu Hukum. Jakarta: Sinar Grafika.

Romli Atmasasmita dan Kodrat Wibowo. (2016). Analisis Ekonomi Mikro Tentang Hukum Pidana Indonesia. Edisi Pertama. Jakarta: Prenadamedia Group.

Romli Atmasasmita. (2018). Pengantar Hukum Kejahatan Bisnis. Edisi Ketiga. Jakarta: Prenadamedia Group.

Roni Wiyanto. (2012). Asas-asas Hukum Pidana Indonesia. Bandung: Mandar Maju.

\section{Jurnal:}

Arif Rohman. "Upaya Menekan Angka Kriminalitas Dalam Meretas Kejahatan Yang Terjadi Pada Masyarakat." Jurnal Perspektif. Volume 21 No. 2 Tahun 2016 Edisi Mei.

Diah Puspita Evariani, Eko Sopoyono, Sularto. "Kebijakan Pertanggungjawaban Pidana Oleh Pelaku Kejahatan Terhadap Harta Benda (Studi Kasus Terhadap Recidivis)". Diponegoro Law Review. Volume 1 Nomor 2 Tahun 2013

Suharyono AR. "Perumusan Sanksi Pidana Dalam Pembentukan Peraturan Perundang-undangan." Jurnal Perspektif. Volume 17 No. 2 Tahun 2012 Edisi Januari.

Yoserwan. "Kebijakan Hukum Pidana Mengenai Pidana Tentang Harta Kekayaan dalam RUU KUHP Indonesia Sebagai Antisipasi Kelebihan Kapasitas Di Lembaga Pemasyarakatan." Jurnal Legislasi Indonesia. Vol. 17 No. 2 Juni 2020.

\section{Website:}

https://www.google.co.id/amp/s/equalpartners.food. blog/2019/03/08/kejahatan-terhadap-hartakekayaan/amp/, diakses pada Jumat, 8 Oktober 2020, Pkl 21.00 WIB. 